\title{
Prevention of Tissue Factor Generation in Mononuclear Cells by Agents Known to Increase Intracellular Cyclic AMP
}

\author{
Tatsuhito Tono-oka, Masayuki Nakayama, Eiki Gotohda \\ and Takeo Takeda \\ Department of Pediatrics, Hokkaido University School of \\ Medicine, Sapporo 060
}

\begin{abstract}
Tono-oka, T., Nakayama, M., Gotohda, E. and Takeda, T. Prevention of Tissue Factor Generation in Mononuclear Cells by Agents Known to Increase Intracellular Cyclic AMP. Tohoku J. exp. Med., 1979, 127 (2), 161-167 Agents known to increase intracellular levels of cyclic 3', 5'adenosine monophosphate (cyclic AMP) were examined for their effect on tissue factor generation by mononuclear cells cultured with $E$. coli endotoxin. Aminophylline, an inhibitor of phosphodiesterase, and epinephrine, a $\beta$-adrenergic agent, showed an inhibitory effect, and these effects were reversible. Moreover, dibutyryl cyclic AMP also exhibited the effect. Dibutyryl cyclic GMP, however, did not enhance the tissue factor generation by mononuclear cells. On the basis of these observations, it was concluded that the phenomenon of tissue factor generation by mononuclear cells is a biological event, and that intracellular cyclic AMP has a possible role in modulating this phenomenon._- tissue factor; mononuclear cell; endotoxin; cyclic AMP
\end{abstract}

Human mononuclear cells cultured with endotoxin generate tissue factor activity (Rickles et al. 1977; Tono-oka 1978). Our previous study demonstrated that the activity is located mainly on the cell membranes, and that amino acids, $\mathrm{Ca}^{++}$, optimal culture temperature and protein synthesis are essential for the development of the activity (Tono-oka 1978). These observations raise the possibility that some metabolic changes of cell membranes triggered by the endotoxin may induce the development of tissue factor activity, and this phenomenon is a true biological event. But its precise biological significance is uncertain.

Recently, attention was directed toward the possibility that cyclic nucleotides might play a role in the modulation of the biologic functions of various types of human leucocytes (Bach 1975; Diamanstein and Ulmer 1975; Hadden et al. 1972; Hirschhorn et al. 1970; Koopman et al. 1973; Strom et al. 1973; Watson et al. 1973). Many workers reported that cyclic GMP enhances the functions of leucocytes; lymphocyte blastogenesis, lymphocyte mediated cytotoxicity, generation of MIF and chemotaxis of granulocyte. On the other hand, cyclic AMP

Received for publication, May 4, 1978.

Address for reprint requests: Dr. Tatsuhito ToNo-oka, Department of Pediatrics, Hokkaido University School of Medicine, N-15, W-7, Sapporo 060, Japan. 
suppresses these functions. Therefore, it is of interest to know whether the tissue factor generation by mononuclear cells is also modulated by cyclic nucleotides.

This study presents evidence that dibutyryl cyclic AMP and several agents known to increase intracellular levels of cyclic AMP are capable of preventing tissue factor generation by mononuclear cells.

\section{Materials and Methods}

Drugs. Aminophylline and epinephrine were purchased from Sigma Chemicals (St. Louis, Mo.) and dibutyryl adenosine $3^{\prime}, 5^{\prime}$ cyclic monophosphate and dibutyryl guanosine $3^{\prime}, 5^{\prime}$ cyclic monophosphate were obtained from Boehringer (Mannheim, GmbH).

Drugs were prepared in a medium of RPMI 1640 and sterilized (Millipore filter 0.45 $\mu \mathrm{m})$ before use.

Cell culture. Peripheral bloods from normal adults and children were collected in sterile pyrogen-free siliconized tubes in which 0.1 the blood volume of $4 \%$ trisodium citrate had been placed. Then the mononuclear cells were separated by a modification of the method of Böyum (1968). This preparation contains $90-95 \%$ of non-phagocyting cells and $5-10 \%$ phagocyting cells. The cells were washed 5 times in ice-cooled citrate saline (l part $0.1 \mathrm{M}$ trisodium citrate +5 parts isotonic saline) to remove platelets, and suspended in a medium of RPMI 1640 at a concentration of $2 \times 10^{6} / \mathrm{ml} .1 \mathrm{ml}$ of the cell suspensions was cultured in duplicate or triplicate with $1 \mu \mathrm{g} / \mathrm{ml}$ of Escherichia coli endotoxin (Difco) in a $12 \times 100 \mathrm{~mm}$ siliconized glass tubes at $37^{\circ} \mathrm{C}$ in a $5 \% \mathrm{CO}_{2}$ media for various periods. After culture, cells were harvested by centrifugation and resuspended in $1 \mathrm{ml}$ of distilled water. Then cell extracts were prepared by 5 times freezing-thawing as previously described (Tono-oka 1978).

Coagulation study. A one stage method was employed in this study. $0.1 \mathrm{ml}$ of factor VIII deficient plasma (Dade) and $0.1 \mathrm{ml}$ of cell extract were incubated together in siliconized tubes at $37^{\circ} \mathrm{C}$ for $2 \mathrm{~min}$, then $0.1 \mathrm{ml}$ of $0.025 \mathrm{M} \mathrm{CaCl}_{2}$ was added, and the clotting time was recorded. In this assay system, measurable procoagulant activity is mainly due to the tissue factor, although minimal influences of cephalin-like activity and anticoagulant activities are not completely excluded. In the preliminary experiments, there was a significant correlation between the results obtained by the one stage method and those obtained by the two stage method introduced by Nemerson (1968).

All drugs used in the experiments were confirmed to have no effect on the clotting time of substrate plasma mixed with brain thromboplastin (Ortho).

\section{RESULTS}

\section{Influences of pharmacological agents on viability of mononuclear cells}

Agents utilized in this study were first examined for their influences on the viability of mononuclear cells by trypan blue dye exclusion method. These drugs produced no significant cytotoxic effect on the cells incubated with them for $6 \mathrm{hr}$ at $37^{\circ} \mathrm{C}$ over the concentration ranges utilized in this study. Effects of agents known to increase intracellular cyclic AMP on tissue factor generation
by mononuclear cells

Two drugs were used, namely aminophylline and epinephrine. The former is an inhibitor of phosphodiesterase, and the latter is an adenyl cyclase activator. 
As previously shown, the clotting time of substrate plasma which had been added with cell extracts before culture is longer than $250 \mathrm{sec}$, but when the extracts were added after the $6-\mathrm{hr}$ culture with $1 \mu \mathrm{g} / \mathrm{ml}$ of endotoxin, it is about 50 sec. Various concentrations of the drugs were added to the culture medium containing $1 \mu \mathrm{g} / \mathrm{ml}$ of endotoxin, and the effects of drugs were estimated on the basis of the clotting time of the substrate plasma. As shown in Fig. 1, aminophylline produced a dose response type inhibition of tissue factor generation by mononuclear cells at concentrations more than $5 \times 10^{-4} \mathrm{M}$. Inhibitory effect was significant at $5 \times 10^{-3}$ M of the drug $(p<0.05)$.

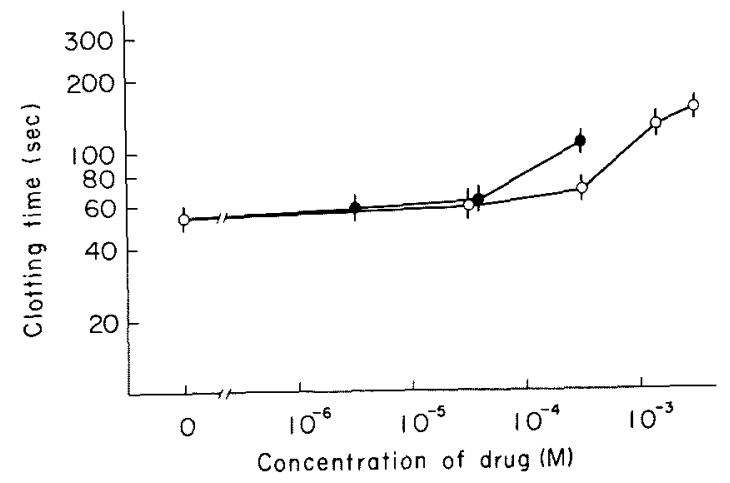

Fig. 1. Effects of aminophylline and epinephrine on tissue factor generation by mononuclear cells. Cells were cultured for $6 \mathrm{hr}$ with various concentrations of drugs in medium RPMI 1640 containing $1 \mu \mathrm{g} / \mathrm{ml} E$. coli endotoxin. Activity of cell extracts was assayed by the one stage method. Three separate experiments were carried out. Results are the mean clotting time $t$ s.E. of six materials. $\bullet-\bullet$, epinephrine; o- o, a minophylline.

Epinephrine also suppressed the tissue factor generation by mononuclear cells at $5 \times 10^{-4} \mathrm{M}$. This effect was also significant at $p<0.05$. But both drugs showed no effect at the concentrations less than $5 \times 10^{-6} \mathrm{M}$.

Then, inhibitory effects of both the drugs were confirmed to be reversible. After several hr of culture with the drug, mononuclear cells were harvested by centrifugation, washed with Hanks solution, then resuspended in RPMI 1640 containing $1 \mu \mathrm{g} / \mathrm{ml}$ of endotoxin. Then, cell culture was continued again for several hr. As shown in Fig. 2, coagulant activity in mononuclear cells which had been suppressed by either of the drugs for several hr started to develop after the drugs were eliminated from the medium.

Effect of dibutyryl cyclic AMP on tissue factor generation by mononuclear cells

In view of the apparent capacity of aminophylline and epinephrine to suppress the tissue factor generation by mononuclear cells, studies were undertaken to determine the effect of dibutyryl cyclic AMP. As shown in Fig. 3, this drug also suppressed the tissue factor generation by mononuclear cells at concentrations higher than $10^{-5} \mathrm{M}$. This inhibitory effect was of a dose response type. This effect 

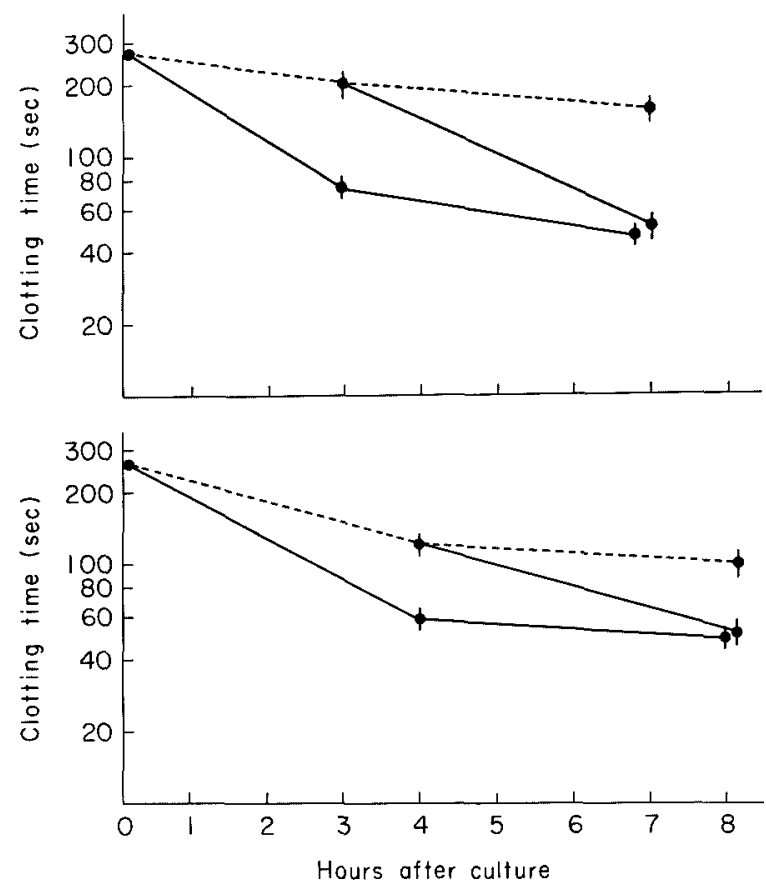

Fig. 2. Effects of aminophylline and epinephrine on tissue factor generation by mononuclear cells. The reversible inhibitory effects of both the drugs were confirmed. After three or four hr of culture with the drug, cells were harvested by centrifugation, and treated as described in text. Results are the mean clotting time \pm s.e. of five materials.

Upper: Cultured with $5 \times 10^{-3} \mathrm{M}$ aminophylline (•...) and cultured with no drug $(\bullet-\bullet)$.

Lower: Cultıred with $5 \times 10^{-4} \mathrm{M}$ epinephrine (•..-) and cultured with no drug $(\bullet-\bullet)$.

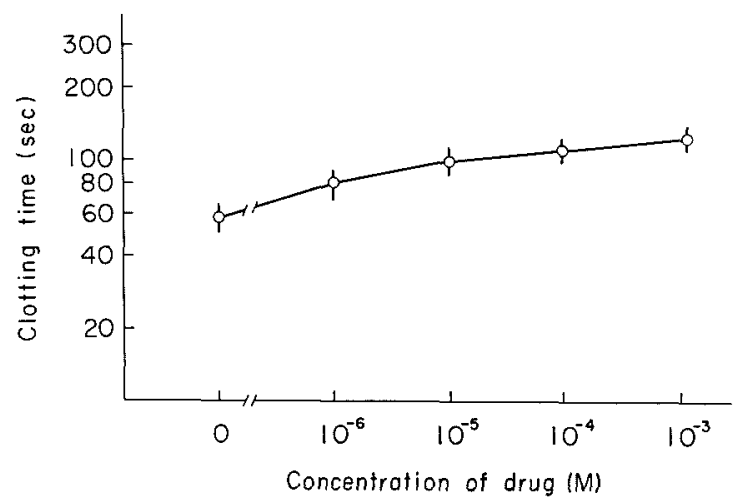

Fig. 3. Effect of dibutyryl cyclic AMP on tissue factor generation by mononuclear cells. Cells were cultured for $6 \mathrm{hr}$ with various concentrations of dibutyryl cyclic AMP in RPMI 1640 containing $1 \mu \mathrm{g} / \mathrm{ml}$ of $E$. coli endotoxin. Activity was assayed by the one stage method. Results are the mean clotting time \pm s.E. of five materials. 
was significant at $10^{-5} \mathrm{M}$ at $p<0.05$.

\section{Effect of dibutyryl cyclic GMP on tissue factor generation by mononuclear cells}

This drug did not show any significant effect on tissue factor generation by mononuclear cells incubated with $1 \mu \mathrm{g} / \mathrm{ml}$ of endotoxin or without endotoxin over a concentration range from $10^{-3} \mathrm{M}$ to $10^{-6} \mathrm{M}$ (data not shown).

\section{Discussion}

Previously, Rickles and co-workers demonstrated that human mononuclear cells cultured with endotoxin developed a high tissue factor activity (1977). Endotoxin, at concentrations found to contaminate many commerical mitogens, activated mononuclear cells in a time-dependent manner. We also observed these effects, and confirmed that the activity of tissue factor is located mainly on the cell membrane (1978). It is still uncertain, however, whether other mitogens or antigens which do not contain any endotoxin have the ability to develop tissue factor activity in mononuclear cells. Furthermore, it is also uncertain whether this phenomenon is a proper function of human mononuclear cells.

Recently, there have been many reports with respect to the action of cyclic nucleotides on human leucocytes (Hirschhorn et al. 1970; Hadden et al. 1972; Koopman et al. 1973; Strom et al. 1973; Watson et al. 1973; Bach 1975; Diamanstein et al. 1975). Generally, it is suggested that a high level of intracellular cyclic GMP leads to the enhancement of leucocyte functions; on the other hand, a high level of intracellular cyclic AMP leads to the suppression of leucocyte functions. Hadden and co-workers suggested that cyclic GMP is a possible intracellular mediator in the case of mitogenic influences in lymphocytes (1972). Furthermore, it has been suggested by Watson and his co-workers that cyclic AMP may be the intracellular mediator of a tolerogenic signal whereas both cyclic AMP and cyclic GMP may be required as mediators of the inductive signal for immune response (1973). Thus it is very interesting and important to study the role of cyclic nucleotides in the tissue factor generation by mononuclear cells.

In the work concerning the action of cyclic AMP on leucocyte functions, $\beta$ adrenergic agents such as isoproterenol or epinephrine which activate adenyl cyclase in a number of tissues, aminophylline or theophylline which are the competitive inhibitors of a phosphodiesterase, and dibutyryl cyclic AMP are usually used to raise the level of intracellular cyclic AMP. In this study we used aminophylline, epinephrine and dibutyryl cyclic AMP, and inhibitory effects were observed with all drugs. Concentrations which showed an inhibitory effect on tissue factor generation by mononuclear cells were parallel with those on various kinds of leucocyte functions reported by many workers (Diamanstein et al. 1975; Hirschhorn et al. 1970; Koopman et al. 1973; Strom et al. 1973). Since these inhibitory effects were reverisble, the effect is not cytotoxic or non-specific.

There seems to be no antagonistic action of cyclic GMP and cyclic AMP as far 
as the tissue factor generation by mononuclear cells is concerned, since dibutyryl cyclic GMP does not show any effect. This means that cyclic GMP may not be an intracellular second messenger in this phenomenon which may be triggered by endotoxin. Although data were not shown, imidazole, an agent known to stimulate cyclic AMP-phosphodiesterase activity in broken cell preparations (Butcher and Sutherland 1962), is incapable of increasing tissue factor activity in mononuclear cells cultured with or without endotoxin. This means that cyclic AMP levels lower than normal do not lead to the enhancement of tissue factor activity in mononuclear cells, whereas higher levels lead to the suppression. In this phenomenon, namely the tissue factor generation by mononuclear cells triggered by coming in contact with endotoxin, what would be the intracellular second messenger? Although this remains obscure, the presence of a messenger system other than cyclic GMP is suggested.

Although Maynard and co-workers demonstrated using cultured amnion cells that tissue factor activity in these cells is not affected by dibutyryl cyclic AMP (1976), this is not applicable to our case, since cell types as well as triggers used in the their experiments are different from ours.

The biological role of this phenomenon is still obscure, but the fact that cyclic AMP acts on it as a suppressor suggests that a suppressive pathway exists in this phenomenon, and it was further demonstrated that this phenomenon is really a biological event.

\section{References}

1) Bach, M.A. (1975) Differences in cyclic AMP changes after stimula tion by Prostaglandin and Isoproterenol in lymphocyte subpopulations. J. clin. Invest., 55, 1074-1081.

2) Böyum, A. (1968) Separation of leucoeytes from blood and bone marrow. Scand.J. clin. Lab. Invest., 21, suppl. 97, 1-109.

3) Butcher, R.W. \& Sutherland, E.W. (1962) Adenosine $3^{\prime}, 5^{\prime}$ phosphate in biological materials. J. biol. Chem., 237, 1244-1250.

4) Diamanstein, T. \& Ulmer, A. (1975) The antagonistic action of cyclic GMP and cyclic AMP on proliferation of $\mathrm{B}$ and $\mathrm{T}$ lymphocytes. Immunology, 28, 113-119.

5) Hadden, J.W., Hadden, E.M., Haddox, M.K. \& Goldberg, N.D. (1972) Guanosine $3^{\prime}, 5^{\prime}$-cyclic monophosphate: A possible intracellular mediator of mitogenic influences in lymphocytes. Proc. Nat. Acad. Sci., 69, 3024-3027.

6) Hirschhorn, R., Grossman, J. \& Weissman, G. (1970) Effect of cyclic $3^{\prime}, 5^{\prime}$-adenosine monophosphate and theophylline on lymphocyte transformation. Proc. Soc. exp. Biol. Med., 133, 1361-1365.

7) Koopman, W.J., Gillis, M.H. \& David, J.R. (1973) Prevention of MIF activity by agents known to increase cellular cyclic AMP. J. Immunol., 110, 1609-1614.

8) Maynard, J.R., Fintel, D.J., Pitlick, F.A. \& Nemerson, Y. (1976) Tissue factor in cultured cells - pharmacologic effects. Lab. Invest., 35, 550-557.

9) Nemerson, Y. (1968) The phospholipid requirement of tissue factor in blood coagula tion. J. clin. Invest., 47, 72-80.

10) Rickles, F.R., Levin, J., Hardin, J.A., Barr, C.F. \& Conrad, M.E. Jr. (1977) Tissue factor generation by mononuclear cells: Effects of endotoxin and dissociation of tissue factor generation from mitogenic response. J. Lab. clin. Med., 89, 792-803.

11) Strom, T.B., Carpenter, C.B., Garovoy, M.R., Austen, K.F., Merrill, J.P. \& Kaliner, M. (1973) The modulating influence of cyclic nucleotides upon lymphocyte-mediated cytotoxicity. J. exp. Med., 138, 381-393. 
12) Tono-oka, T. (1978) Davelopment of tissue factor activity in mononuclear cells cultured in vitro. Tohoku J. exp. Med., 125, 213-222.

13) Watson, J., Epstein, R. \& Cohn, M. (1973) Cyclic nucleotides as intracellular mediators of the expression of antigen-sensitive cells. Nature, 246, 405-409. 